\title{
PENINGKATAN KEMAMPUAN SISWA MENULIS CERITA KARANGAN MENGGUNAKAN MEDIA GAMBAR
}

\author{
Oleh: Taqwa dan Harlina M.Bakri
}

Fakultas Tarbiyah \& IImu Keguruan IAIN Palopo

\begin{abstract}
Abstrak
Tulisan ini merupakan hasil dari Penelitian Tindakan Kelas ( PTK) yang menggunakan siklus Perencanaan, Tindakan, Observasi, dan Refleksi. Masalah utama dalam tulisan ini adalah rendahnya Kemampuan menulis cerita karangan pada siswa kelas V MI DDI I Palopo mata pelajaran Bahasa Indonesia, Penelitian tindakan kelas ini secara umum untuk memperbaiki kualitas pembelajaran di MI DDI I Palopo dan secara khusus bertujuan untuk meningkatkan hasil belajar Bahasa Indonesia pada siswa kelas V MI DDI I Palopo. Subjek penelitian ini adalah siswa kelas V.B MI DDI I Palopo pada semester ganjil tahun pelajaran 2016/2017 dengan jumlah siswa 33 orang. yang dilaksanakan sebanyak dua siklus dengan materi menulis karangan narasi dan deskripsi. Alat pengumpul data yang digunakan terdiri dari instrumen pembelajaran, evaluasi (tes dan non tes),Dokumentasi, serta observasi untuk mengetahui validasi data. Hasil penelitian menunjukkan bahwa dengan menggunakan media gambar hasil belajar siswa setiap siklusnya mengalami perubahan secara signifikan. Secara berturut-turut (berdasarkan siklus (I dan II) hasil belajar Bahasa Indonesia materi pokok menulis cerita karangan siswa kelas V MI DDI I Palopo, diperoleh bahwa rata rata hasil belajar siswa pada siklus I adalah sebesar 61,48 termaksud dalam kategori belum mencapai nilai KKM dengan jumlah siswa yang tuntas belajar adalah 16 siswa dengan peresentase 45,45\%, dan hasil belajar pada siklus II rata rata diperoleh 77,27 termaksud dalam kategori baik dengan jumlah siswa yang tuntas 30 dengan persentase sekitar $75,75 \%$, disamping itu aktifitas siswa dan aktifitas guru juga mengalami peningkatan dari pertemuan pertama hingga pertemuan terakhir baik dari siklus I maupun siklus II.
\end{abstract}

\section{Kata Kunci: Menulis Cerita Karangan, Media Gambar}

\section{A. Pendahuluan}

\section{Latar Belakang Masalah}

Pembelajaran Bahasa Indonesia adalah salah satu mata pelajaran yang wajib ada di setiap sekolah di Indonesia, mulai dari pendidikan di sekolah dasar hingga menengah pertama. Dalam pembelajaran Bahasa Indonesia terdapat 4 keterampilan berbahasa yang harus dikuasai oleh siswa, yaitu keterampilan mendengarkan (menyimak), berbicara, membaca dan menulis yang memiliki manfaatnya masing-masing. Keterampilan berbahasa yang paling rumit diantara 4 
keterampilan yang telah disebutkan di atas yaitu keterampilan menulis. Alasannya, karena keterampilan menulis membutuhkan pemahaman yang mendalam, tenaga yang semaksimal mungkin dan harus membutuhkan konsentrasi yang tinggi di bandingkan dengan keterampilan berbahasa yang lain.

Seperti yang dikatakan oleh H.G.Tarigan sebagaimana dikutip oleh Maryani T.Permana bahwa menulis ialah:1

“... menurunkan atau melukiskan lambang grafik yang menggambarkan suatu bahasa yang dipahami oleh seseorang sehingga orang lain dapat membaca lambing-lambang grafik tersebut kalau mereka memehami bahasa dan gambar grafik tersebut".

Menulis merupakan salah satu kegiatan yang memberikan banyak manfaat positif bagi perkembangan seorang siswa. Berbeda dari manfaat yang telah disebutkan sebelumnya, manfaat yang dirasakan oleh siswa secara personal diantaranya, dengan menulis siswa lebih bisa berfikir secara aktif, kritis dan kreatif, bertanggung jawab atas apa yang hendak disampaikan melalui tulisannya, serta membuat tulisan siswa menjadi lebih rapi dan terlihat indah.

Lebih dari pada itu siswa lebih leluasa dan penuh penghayatan dalam menuangkan hasil pemikiran dan ide-ide yang dimilikinya, keinginannya, apa yang ia rasakan ke dalam bentuk tulisan yang ia buat tanpa harus dibatasi. Menulis juga dapat membuat sifat emosional dan daya nalar siswa menjadi lebih matang dan terarah karena diasah terus-menerus dengan melakukan latihan menulis.

Selain itu, siswa juga dapat menginspirasi banyak orang melalui karya tulisan yang ia ciptakan. Jika seorang siswa mampu menciptakan suatu tulisan yang mengagumkan dan diminati oleh banyak orang, dan terlebih jika isi tulisan itu menyentuh banyak orang, apalagi jika penggunaan kalimatnya tepat maka sudah dapat dipastikan bahwa siswa tersebut mempunyai bakat dalam bidang menulis.

Namun, tidak semua siswa mempunyai bakat yang demikian. Karena kegiatan menulis ini sulit dan tidak mudah untuk dilakukan. Alasannya, karena

1 Maryani T.Permana,"Meningkatkan Kemampuan Siswa dalam Menulis Karangan Melalui Penggunaan Media Gambar Seri di Kelas V SDN Cibulan II Desa Cibulan Kecamatan Lemahsugi Kabupaten Majalengka", (Skripsi-Universitas Pendidikan Indonesia:Majalengka, 2009), h.2. ( diakses 25 April 2016 ) 
kegiatan menulis memerlukan waktu latihan yang cukup lama, bahkan bisa sampai berbulan-bulan dan dengan pengkajian yang mendalam secara berulang-ulang pula untuk dapat menjadi penulis sejati yang terkenal dan berbakat.

Kesulitan dan masalah yang sering dan paling awal kita jumpai pada kebanyakan siswa yaitu mereka sangat sulit untuk bagaimana caranya memulai suatu kegiatan menulis. Inilah yang biasanya menghambat siswa untuk menemukan sebuah ide/gagasan yang akan ditulisnya (sulit berimajinasi ) karena mereka hanya berfokus pada satu masalah saja yaitu bagaimana cara untuk memulainya. Siswa tidak mengetahui bagaimana cara merangkai, menghubungkan kata-kata untuk menjadi sebuah kalimat yang indah dan padu. Biasanya, seorang siswa juga mengalami kesulitan dalam hal penggunaan kalimat yang tepat dan penempatan tanda bacanya.

Terlebih lagi, kita sebagai pendidik kurang mampu menggunakan berbagai macam media, model, metode serta strategi yang sesuai dengan dunia anak SD yang dapat membantu siswa menjadi lebih termotivasi lagi dalam melaksanakan proses pembelajaran, khususnya pembelajaran keterampilan menulis cerita karangan berdasarkan media gambar.

Sebagai seorang guru yang juga merangkap sebagai seorang pendidik, penting untuk mengubah persepsi para siswa yang mengatakan bahwa menulis itu menyusahkan dan juga membosankan kepada persepsi yang mengatakan bahwa kegiatan menulis itu adalah kegiatan yang menyenangkan dan juga mengasyikkan untuk dilakukan.

\section{Rumusan Masalah}

Berdasarkan latar belakang di atas, dirumuskan masalah dalam tulisan ini adalah sebagai berikut : "Apakah penggunaan gambar sebagai media pembelajaran dapat meningkatkan kemampuan siswa menulis cerita karangan pada kelas $\mathrm{V} \mathrm{Ml}$ DDI I Palopo?"

\section{Manfaat yang Diperoleh}

Manfaat yang diharapkan dalam adalah :

a. Bagi siswa, dapat membantu peserta didik dalam membuat cerita karangan dengan lebih baik lagi melalui penggunaan media gambar. 
b. Bagi guru, dapat membantu guru memberikan pengalaman dan pengetahuan dalam menerapkan media gambar pada pembelajaran Bahasa Indonesia untuk meningkatkan kemampuan siswa dalam membuat cerita karangan di kelas $\mathrm{V}$ MI DDI I Palopo.

c. Bagi sekolah, diharapkan dapat digunakan untuk meningkatkan kualitas pembelajaran di sekolah dan kepala sekolah bisa merekomendasikan penelitian ini serta penelitian ini bisa diadaptasi ke pembelajaran yang lain.

d. Bagi pengembangan ilmu, dapat dijadikan sebagai sumber referensi dan sebagai acuan pengembangan ilmu pengetahuan yang selanjutnya.

\section{B. Kajian Pustaka}

\section{Hakikat Menulis dalam Pembelajaran Bahasa Indonesia}

Bahasa merupakan produk budaya yang berharga dari generasi ke generasi berikutnya. Bahasa adalah hasil budaya yang hidup dan berkembang dan harus dipelajari. Dengan bahasa manusia dapat memberi nama segala sesuatu yang pernah dialami, diamati, baik yang tampak maupun tidak tampak.

Teilhard seorang peneliti bahasa:

"pada diri manusia ada kemampuan otak yang kodrati untuk melaksanakan refleksi dan kebebasan, kemampuan ini akan berkembang apabila dibudayakan melalui lingkungan." Dari pendapat di atas, menunjukkan bahwa bahasa bukan hanya alat komunikasi antarmanusia, tetapi sebagai alat pengembangan intelektual untuk mencapai kesejahteraan sosial manusia. ${ }^{2}$

Dalam Kurikulum 2004 dinyatakan bahwa :3

Standar kompetensi Bahasa dan Sastra Indonesia berorientasi pada hakikat pembelajaran bahasa, yaitu berbahasa adalah belajar berkomunikasi dan belajar sastra adalah belajar menghargai manusia dan nilai-nilai kemanusiaan. Oleh karena itu pembelajaran Bahasa dan Sastra Indonesia diarahkan untuk meningkatkan kemampuan siswa untuk berkomunikasi, baik secara lisan maupun secara tertulis.

2Zulela, Pembelajaran Bahasa Indonesia, (Cet.Il; Bandung: PT.Remaja Rosdakarya, 2012), h.3-4.

${ }^{3}$ E.Emalia SD Negeri 4 Mangunjaya, "Pembelajaran Bahasa Indonesia di Sekolah Dasar, "Situs Resmi SD Negeri 4 Mangunjaya. http://sdn4mangunjaya. blogspot.co.id/2013/09/pemnbelajaran-bahasaindonesia-d.html (diakses 01 Mei 2016 ). 
Pengajaran menulis, baik di sekolah dasar maupun di jenjang yang lebih tinggi pada hakikatnya merupakan pengajaran yang aktif produktif, yaitu menghasilkan (menghasilkan pesan), yang hasilnya nanti berupa tulisan. Pengajaran menulis ini dapat meningkatkan pengembangan kecerdasan siswa untuk berbagai aspek, mengembangkan daya inisiatif dan kreativitas, serta menumbuhkan keberanian dan mendorong kemauan dan kemampuan mengumpulkan informasi. ${ }^{4}$

\section{Tujuan dan Fungsi Menulis dalam Pembelajaran Bahasa Indonesia}

Pada prinsipnya, fungsi utama dari tulisan adalah sebagai alat komunikasi yang tidak langsung. Menulis sangat penting bagi pendidikan karena memudahkan para pelajar berfikir. Juga dapat menolong kita berfikir kritis. Selain itu, dapat mempermudah kita merasakan hubungan-hubungan, memperdalam daya serap dan tanggap atau persepsi kita, memecahkan masalah-masalah yang sedang kita hadapi.

Peneliti lain dapat menjelaskan bahwa fungsi menulis terbagi dalam empat fungsi. 5

1. Fungsi penataan

Artinya proses dari membuat sebuah karangan disana terjadi sebuah penataan/pengelolaan gagasan, pikiran, pendapat, imajinasi dan yang lainnya.

2. Fungsi pengawetan,

Artinya fungsionalitas gagasan dapat di operasionalkan hingga bertahan lama, hal ini terimplementasi bahwa gagasan akan terdokumentasi dalam sebuah tulisan.

3. Fungsi penciptaan,

Artinya hasil dari karangan merupakan perwujudan dari hal yang baru. Dan yang terakhir fungsi penyampaian, artinya isi yang ada dalam sebuah karangan meupakan gagasan yang akan disampaikan penulis terhadap pembacanya.

4. Fungsi penyampaian

Gagasan, pikiran, imajinasi itu yang sudah ditata dan diawetkan dalam wujud tulisan dapat dibaca atau disampaikan kepada yang lain.

\footnotetext{
${ }^{4}$ Masnur Muslich, Melaksanakan PTK Itu Mudah (Classroom Action Research) Pedoman Praktis bagi Guru Profesional, (Cet.Vl; Jakarta: PT.Bumi Aksara, 2012), h.119-120.

5 Tri Wahyudi, "Tugas Kuliah," Blog Tri Wahyudi. http://weachyudhiepunya.blogspot.co.id/2014/06/pengertian-fungsi-dan-tujuan-menulis.html (05 Mei 2016)
} 


\section{Pembelajaran Keterampilan Menulis Karangan}

\section{a) Pengertian Keterampilan Menulis}

Berdasarkan asal katanya, keterampilan berasal dari kata terampil. Yang artinya mahir, mampu, cakap, gesit, dan cekatan, dalam melakukan sesuatu hal dengan sangat baik. Setiap keterampilan itu erat sekali berhubungan dengan tiga keterampilan lainnya dengan cara yang beraneka ragam. Dalam memperoleh keterampilan berbahasa, biasanya kita melalui suatu hubungan urutan yang teratur: pada masa kecil kita belajar menyimak bahasa kemudian berbicara, sesudah itu kita belajar membaca dan menulis. 6

Selanjutnya, kata menulis mempunyai dua arti. Pertama, menulis berarti mengubah bunyi yang dapat didengar menjadi tanda-tanda yang dapat dilihat. Bunyi-bunyi yang diubah itu bunyi bahasa, yaitu bunyi yang dihasilkan oleh alat ucap manusia (mulut dan perangkat kelengkapannya: bibir, lidah, gigi, dan langitlangit). Kedua, kata menulis mempunyai arti kegiatan mengungkapkan gagasan secara tertulis. Orang yang melakukan kegiatan ini dinamakan penulis dan hasil kegiatannya berupa tulisan. ${ }^{7}$

Menulis merupakan sebuah proses kreatif menuangkan gagasan dalam bentuk bahasa tulis untuk tujuan, misalnya, memberi tahu, meyakinkan, menghibur. Hasil dari proses kreatif menulis ini biasa disebut dengan istilah tulisan atau karangan. ${ }^{8}$.

Keterampilan menulis merupakan salah satu jenis keterampilan berbahasa yang harus dikuasai setiap siswa dalam mengikuti pembelajaran Bahasa Indonesia. Banyak ahli telah mengemukakan pengertian menulis. Menurut pendapat Saleh Abbas, keterampilan menulis adalah kemampuan mengungkapkan gagasan, pendapat, dan perasaan kepada pihak lain dengan melalui bahasa tulis. Ketepatan pengungkapan gagasan harus didukung dengan ketepatan bahasa yang digunakan, kosakata dan gramatikal dan penggunaan ejaan.

6 Joko Karyadi,"Peningkatan Keterampilan Menulis Karangan dengan Model Pembelajaran Kooperatif Siswa Kelas III SD Negeri 3 Urutsewu Ampel Boyolali",(Skripsi-Sebelas Maret:Boyolali, 2010), h.22 ( diakses 01 Mei 2016)

${ }^{7}$ Asul Wiyanto, Terampil Menulis Paragraf, (Cet.ll; Jakarta: PT. Grasindo, Juli 2006), h. 1-2.

${ }^{8}$ Daeng Nurjamal, et.al. Terampil Berbahasa, (Cet.ll; Bandung: Bumi Aksara 2011), h. 69. 
Untuk menguasai keterampilan menulis, ada baiknya kita memperhatikan beberapa aspek penting yang dapat membantu dan memudahkan kita dalam menulis. Seperti, kita harus fokus, menanamkan dan memantapkan niat yang sungguh-sungguh dalam hati bahwa kita bisa dan mampu untuk melakukannya. Selanjutnya, untuk menguasai keterampilan menulis itu sendiri kita harus memperbanyak proses latihan.

dari uraian di atas dapat di simpulkan bahwa menulis sebagai sebuah keterampilan berbahasa adalah kemampuan seseorang dalam mengemukakan gagasan, perasaan, dan pikiran-pemikirannya kepada orang atau pihak lain dengan menggunakan media tulisan.

\section{b) Aspek motivasi dalam menulis}

Biasanya, ide muncul kepada dari diri seseorang yang sedang ada dalam masalah atau ia sedang menyendiri di suatu tempat. Jika ide kita tak kunjung muncul, maka sebaiknya kita mengingat hal-hal/ peristiwa yang kita alami yang telah terjadi beberapa tahun lalu untuk memancing ide itu untuk keluar. Yang nantinya pengalaman yang kita rasakan itu dapat dijadikan sebagai acuan dalam menulis sebuah cerita mengenai pengalaman hidup kita.

c) Jenis-Jenis Karangan

Karangan adalah salah satu bentuk atau produk bahasa tulis yang isinya mengungkapkan suatu ide, pengalaman, dan pengetahuan seseorang untuk dibaca berbagai kalangan. Alwi menyatakan karangan merupakan rentetan kalimat yang berkaitan yang menghubungkan proposisi yang satu dengan proposisi lain sehingga membentuk kesatuan yang cerita, buah pena, ciptahan, gubahan, cerita mengadaada, dan hasil rangkaian. ${ }^{9}$

Mengarang adalah keseluruhan kegiatan seseorang dalam merangkai dan mengungkapkan gagasan yang dimilikinya untuk dapat disampaikan melalui bentuk suatu tulisan kepada masyarakat serta para pembaca untuk dipahami tujuan dan maksud dari tulisan yang dibuat oleh seorang pengarang.

${ }^{9}$ Sukirman Nurdjan, Edhy Rustan, Kunci Sukses Berbahasa Indonesia, (Palopo, Desember 2010 ), h. 132. 
Kesimpulannya, karangan adalah hasil karya yang berupa tulisan seorang pengarang yang berisikan imajinasinya yang dituangkan kedalam suatu media hingga membentuk suatu cerita.

Suatu tulisan atau karangan dapat dikatakan terbentuk secara sistematis antara lain apabila : 10

1) Terdapat relevansi yang baik antara judul dengan bagian pendahuluan, bagian isi, dan bagian penutup tulisan;

2) Terdapat relevansi yang baik antara bagian awal/ pendahuluan dengan bagian isi dengan bagian akhir/penutup tulisan, atau sebaliknya;

3) Terdapat relevansi antar kalimat/klausa yang satu dengan kalimat/klausa yang lain dalam tiap alinea; dan

4) Terdapat relevansi yang pas antara isi tulisan dengan tujunnya.

Ada berbagai macam bentuk jenis karangan yang ada. Diantaranya yaitu karangan narasi, deskripsi, eksposisi, argumentasi, dan persuasi. Berikut penjelasan dari kelima jenis karangan tersebut.

1) Karangan Narasi.

2) Karangan Deskripsi.

3) Karangan Eksposisi.

4) Karangan Argumentasi.

5) Karangan Persuasi.

\section{Media Gambar Pembelajaran Bahasa Indonesia}

a) Pengertian Media Pembelajaran.

Kata media berasal dari bahasa jamak dari kata medium yang secara harfiah berarti perantara/pengantar. Atau media adalah perantara/pengantar dari pengirim ke penerima pesan. ${ }^{11}$ Nurulbiyati dalam Khaeruddin menjelaskan bahwa media adalah segala bentuk alat yang dapat digunakan untuk menuntun/membimbing anak dalam masa pertumbuhan-nya agar kelak menjadi manusia yang berkepribadian /memilikiakhlak yang baik. ${ }^{12}$

10 Ibid., h. 72.

${ }^{11}$ Arief S. Sardiman dkk, Media Pendidikan ( Cet. I ; Jakarta : Rajawali, 1996), h.6.

12 Khaeruddin, IImu Pendidikan Islam ( Cet.. ; Berkah Utami, 2002), h.75. 
Zakiah Daradjat memberikan defenisi tentang alat pendidikan (media) dengan mengatakan bahwa alat pendidikan (media) saat ini adalah Audio Visual Aids (AVA). ${ }^{13}$ Dari pengertian diatas, maka ditarik kesimpulan bahwa media pembelajaran adalah seperangkat alat yang digunakan untuk mempermudah kita dalam menangkap dan menerima pesan.

\section{b) Fungsi Media Pembelajaran}

Pada awalnya media hanya berfungsi sebagai alat bantu dalam kegiatan belajar mengajar yakni berupa sarana yang dapat memberikan pengalaman visual kepada siswa dalam rangka mendorong motivasi belajar, memperjelas dan mempermudah konsep yang kompleks dan abstrak menjadi lebih sederhana, konkrit, serta mudah dipahami. Dengan demikian media dapat berfungsi untuk mempertinggi daya serap dan retensi anak terhadap materi pembelajaran. ${ }^{14}$

Menurut Kemp \& Dayton, media pembelajaran dapat memenuhi tiga fungsi utama apabila media itu digunakan untuk perorangan, kelompok, atau kelompok pendengar yang besar jumlahnya, yaitu (a) memotivasi minat atau tindakan, (b) menyajikan informasi dan, (c) memberi instruksi. 15

\section{c) Manfaat Media Pengajaran}

Sesuai dengan kutipan Azhar Arsyad dan John Lenon mengatakan bahwa manfaat media pengajaran khusus alat-alat pandang yaitu: 16

1) Menarik minat.

2) Meningkatkan pengertian siswa.

3) Memberikan daya yang kuat.

4) Memadatkan informasi.

5) Memudahkan menafs

\section{d) Pengertian Media Gambar}

Media gambar merupakan bagian yang utuh dari media grafis tersebut karena pada dasarnya media gambara merupakan kumpulan dari beberapa titik dan

13 Ibid.

14 H.Asnawir dan M.Basyiruddin Usman, Media Pembelajaran, (Cet. I; Jakarta: Ciputat Pers, Juni 2002), h. 20.

15 Azhar Arsyad, Media Pembelajaran, ( Cet. I ; Jakarta : PT.Raja Grafindo Persada, 2006), h.39.

16 Azhar Arsyad, Bahasa Arab dan Metode Pengajarannya : Beberapa pokok pikiran (Ujung Pandang, Fakultas Tarbiyah IAIN Ujung Pandang, 1997), h.68-69. 
garis yang memvisualisasikan gambara sebuah benda atau seorang tokoh yang dapat memperjelas kita dalam memahami benda atau tokoh tersebut. Dalam pembelajaran di sekolah dasar media.

gambar sangat baik di gunakan dan di terapkan dalam proses belajar mengajar sebagai media pembelajaran karena media gambar ini cenderung sangat menarik hati siswa sehingga akan muncul motivasi untuk lebih ingin menegtahui tentang gamabar yang dijelaskan dan gurupun dapat menyampaikan materi dengan optimal melalui media gamabar tersebut. 17

\section{Cara Penerapan Media Gambar dalam Pembelajaran Menulis}

Berikut ini adalah langkah-langkah dalam menulis karangan berdasarkan gambar: 18

a) Berilah judul yang sesuai.

b) Apabila gambar belum urut, urutkan gambar-gambar yang ada secara logis.

c) Buatlah kalimat yang menceritakan gambar tersebut.

d) Susunlah kalimat-kalimat tersebut dengan baik, sehingga menjadi sebuah cerita.

\section{Metode Penelitian}

\section{Pendekatan dan Jenis Penelitian}

Penelitian ini menggunakan pendekatan yang bersifat kuantitatif dengan menggunakan model pembelajaran kontekstual (Contextual Teaching and Learning) yang bertujuan untuk mengaktifkan siswa dalam proses pembelajaran dengan mengaitkan antara materi pembelajaran dengan kehidupan sehari-hari. Model pembelajaran kontekstual ini sangat efektif untuk di terapkan dalam proses kegiatan belajar khususnya keterampilan menulis. Karena siswa di ajar untuk menemukan masalah dan menyelesaikan sendiri masalah yang di temukan selama proses pembelajaran berlangsung. Jawaban yang telah ada tidak lantas diterima begitu saja oleh siswa, melainkan siswa diajak untuk berdiskusi bersama untuk mengambil kesimpulan yang telah disepakati.

17 Michael Donny, "Penggunaan Media Gambar Dalam Proses Belajar Mengajar,"Blog Agus Ramadhani. http://pendas2013.blogspot.co.id/2013/01/penggunaan-media-gambar-dalam-proses.html (01 Mei 2016)

18 Tugino Thok, " Media Belajar Tempat Berbagi Ilmu dan Pengalaman,"Blog Mas Tugino. http://mastugino.blogspot.co.id/2012/12/menyusun-paragraf-berdasarkan-gambar.html (01 Mei 2016) 
Adapun jenis penelitian ini menggunakan Penelitian Tindakan Kelas (PTK) jenis Empirik. Pengertian PTK itu sendiri yaitu penelitian yang dirancang, dilaksanakan, dan dianalisis oleh guru yang bersangkutan dalam rangka ingin memecahkan masalah pembelajaran yang dihadapinya di dalam kelas dengan salah satu tujuannya yaitu akan terjadinya perbaikan atau peningkatan kualitas penggunaan media, alat bantu belajar, atau sumber belajar lainnya.

\section{Lokasi dan Subjek Penelitian}

Penelitian ini dilaksanakan di sekolah MI DDII PALOPO kelas V.B pada mata pelajaran Bahasa Indonesia tahun ajaran 2016/2017 yang berlokasi di Jl. Datuk Sulaiman Kecamatan Wara Timur Kelurahan Ponjalae. Pengambilan lokasi penelitian ini berdasarkan atas tempat sewaktu peneliti melaksananakan Praktek Pelatihan Lapangan (PPL).

\section{Sumber Data}

Sumber data utama dalam penelitian ini adalah siswa yang menjadi objek dalam penelitian, dengan menerapkan media gambar.

\section{Teknik Pengumpulan Data}

Dalam pengumpulan data, secara garis besar penulis akan menggunakan beberapa teknik sebagai berikut: 19
a) Teknik observasi
b) Teknik wawancara (Interview)
c) Teknik dokumentasi
d) Teknik angket
e) Tes

\section{Teknik Pengolahan dan Analisıs Data}

Karena yang digunakan dalam penelitian ini adalah pendekatan yang bersifat kuantitatif, maka teknik analisis data yang digunakan dalam penelitian ini adalah analisis data secara kuantitatif juga. Data yang terkumpul dari hasil observasi dianalisis secara kuantitatif, sedangkan data hasil belajar kemampuan siswa dianalisis secara kuantitatif juga dengan menggunakan analisis data deskriptif.

19 Muhadi,Penelitian Tindakan Kelas Panduan Wajib Bagi Pendidik, (Cet.I ; Yogyakarta: Shira Media,2011). h. 112. 
a) Analisis Aktifitas Siswa

Data dari hasil observasi aktivitas siswa diperoleh dari pengamatan yang dilakukan oleh observer yang telah ditentukan sebelumnya. Data tersebut dianalisis secara deskriptif.

b) Analisis Aktivitas Guru

Data hasil observasi guru selama kegiatan proses pembelajaran berlangsung dianalisis dan di deskripsikan secara kualitatif guna mencari kekurangan yang terjadi pada setiap pertemuan kemudian diperbaiki pada pertemuan selanjutnya.

c) Siswa dikatakan tuntas belajar secara individual jika siswa tersebut telah memperoleh nilai minimal 70 .

Rumus : N.A $=\frac{S P}{S T} \times 100 \%$

Keterangan : Nilai akhir

$\mathrm{SP}=$ Skor Akhir

ST $=$ Skor Total 20

\section{Siklus Penelitian}

Penelitian PTK ini menggunakan model Hopkins yang dijelaskan sesuai dengan gambar yang ada. Menurt Hopkins, pelaksanaan penelitian tindakan dilakukan membentuk spiral yang dimulai dari merasakan adanya masalah menyusun perencanaan, melaksanakan tindakan melakukan observasi mengadakan refleksi, melakukan rencana ulang, melaksanakan tindakan, dan seterusnya. ${ }^{21}$

Penelitian ini dilakukan sebanyak 2 siklus diamana pada siklus I dilaksanakan 4 kali pertemuan dan siklus II dilaksanakan sebanyak 4 kali pertemuan. Pada setiap siklus terdiri dari beberapa tahap sesuai dengan tahapantahapan pada penelitian tindakan kelas, kecuali pada siklus II dilakukan perbaikanperbaikan sesuai dengan hasil refleksi pada siklus I. Seperti yang dikemukakan oleh

${ }^{20}$ Muh. Uzer Usman, "Upaya Optimalisasi Kegiatan Belajar Mengajar" (Bandung : Rosdakarya, 1993), hIm 136.

21 Wina Sanjaya, Penelitian Tindakan Kelas, (Cet.l; Bandung: Kencana Prenada Media Group, 2009), h. 53-54. 
Suryono bahwa jumlah siklus yang dilakukan bergantung pada kepuasan peneliti tetapi hendaknya lebih dari 1 siklus minimal 2 siklus. ${ }^{22}$

\section{Indikator Keberhasilan}

Indikator keberhasilan dalam penelitian ini apabila kemampuan siswa menulis cerita karangan pada pembelajaran Bahasa Indonesia di kelas V MI DDI I Palopo mengalami peningkatan pada setiap siklusnya. Dan rata-rata hasil belajar kemampuan siswa kelas V MI DDI I Palopo mengalami peningkatan setelah diterapkan media gambar dengan skor 70 .

\section{Hasil Penelitian}

\section{Deskripsi Kondisi Awal}

Rendahnya kemampuan siswa menulis cerita karangan disebabkan oleh guru di sekolah MI DDI I Palopo belum menerapkan media dan model pembelajaran yang pas dalam pembelajaran Bahasa Indonesia dengan materi menulis cerita karangan khususnya menulis karangan deskripsi dan narasi. Akibatnya, siswa tidak mengetahui bagaimana cara memulai kegiatan menulis cerita karangan dengan menarik, siswa merasa bosan dan jenuh, sulit untuk menghubungkan kalimat, tidak ada yang menarik dari pembelajaran menulis cerita karngan, dan terlebih lagi sulit untuk menemukan judul dalam menulis sebuah cerita karangan.

Proses pembelajaran Bahasa Indonesia dilaksanakan dengan langkah-langkah pembelajaran sebagai berikut: pertama, guru menjelaskan sedikit tentang materi yang akan dipelajari tanpa memberikan salam terlebih dahulu, kedua, guru belum menggunakan media gambar saat mengajarkan materi pokok menulis cerita karangan. Setelah itu, guru langsung memberikan siswa tugas dengan penjelasan yang sangat singkat. Siswa juga disuruh membaca buku paket dan merangkum sementara guru sibuk melaksanakan kegiatan lain, seperti mengerjakan administrasi, bercerita dengan guru lain, ketiga hasil pekerjaan/tugas siswa langsung dikumpulkan untuk dinilai tanpa di nilai langsung saat itu juga dan tidak melakukan perbaikan dengan tugas tersebut. Sehingga pembelajaran yang berlangsung hanya terjadi satu arah saja. Guru aktif bertanya sedangkan para siswa hanya duduk sebagai objek yang pasif.

22 Piet A. Suhertian, konsep dasar dan teknik supervise pendidikan, (Cet;) Jakarta: Rineka Cipta, 2000), hlm, 60. 
Dengan adanya alasan tersebut, sehingga mendorong peneliti untuk melaksanakan penelitian dengan menerapkan media gambar dengan memakai model pembelajaran Contekstual Teaching and Learning berupa gambar-gambar yang berada disekitar siswa yang berguna untuk menarik perhatian serta meningkatkan kemampuan siswa menulis cerita karangan. Apabila nilai kemampuan awal siswa dikolompokan dalam lima kategori maka hasil kemampuan awal siswa dipaparkan sebagai berikut:

Kategorisasi Kemampuan Awal Siswa

\begin{tabular}{|c|c|c|c|}
\hline Rentang skor & Kategori & Frekuensi & Persentase \\
\hline $0-20$ & Sangatkurang & 3 & $9,090 \%$ \\
\hline $21-40$ & Kurang & 13 & $39,39 \%$ \\
\hline $41-60$ & Cukup & 10 & $30,30 \%$ \\
\hline $61-80$ & Baik & 6 & $18,18 \%$ \\
\hline $80-100$ & Sangat baik & 1 & $3,030 \%$ \\
\hline \multicolumn{2}{|c|}{ Jumlah } & $\mathbf{3 3}$ & $\mathbf{1 0 0 \%}$ \\
\hline
\end{tabular}

\section{Deskripsi siklus I}

\section{a) Perencanaan tindakan}

1) Peneliti bersama wali kelas V.B mengadakan diskusi dan selanjutnya menyusun Rencana Pelaksanaan Pembelajaran, menyiapkan media pembelajaran dan instrumen-instrumen lainnya.

2) Mempersiapkan instrumen pengamatan (observasi) aspek-aspek proses pembelajaran yang dilakukan guru dan aktivitas siswa dalam kegiatan pembelajaran.

3) Guru menggunakan teknik Tanya jawab untuk membuat siswa lebih aktif lagi dalam melaksanakan proses pembelajaran menulis cerita karangan, sehingga siswa tidak bersifat pasif lagi seperti pada pratindakan sebelumnya.

4) Mengadakan tes dengan menggunakan gambar yang bersifat kontekstual dengan gambar yang berhubungan dengan kebersihan untuk mengetahui sampai sejauh mana siswa mengerti pemaparan materi yang diberikan dalam mengaplikasikan membuat karangan dengan melihat gambar.

\section{b) Pelaksanaan Tindakan}

1) Guru melakukan langkah pembelajaran sesuai dengan skenario pembelajaran (rencana pembelajaran terlampir). 
2) Siswa mengikuti kegiatan pembelajaran dan melaksanakan kegiatan sesuai dengan skenario kegiatan belajar mengajar.

3) Pengamat melakukan pengamatan sesuai dengan instrumen pengamatan tentang aspek-aspek proses pembelajaran yang dilakukan guru dan aktivitas siswa dalam kegiatan pembelajaran.

Adapun data hasil evaluasi dalam kegiatan pembelajaran materi pokok menulis cerita karangan khususnya karangan deskripsi dan karangan narasi. adalah seperti pada tabel berikut:

Pada tabel tersebut, setiap masing-masing siswa mendapat hasil nilai akhir siklus pertama dari proses pembelajaran menulis cerita karangn deskripsi dan narasi. Nilai hasil akhir tersebut ditentukan peneliti dengan melihat hasil yang diperoleh siswa selama mengerjakan soal-soal evaluasi siklus 1.

\section{Hasil Evaluasi siklus 1}

\begin{tabular}{|c|l|c|}
\hline No & \multicolumn{1}{|c|}{ Nama } & Skor \\
\hline 1 & Muh.Safir & 45 \\
\hline 2 & Sahrul Gunawan & 40 \\
\hline 3 & Nur Ainun & 58 \\
\hline 4 & Nurul Miftahul Jannah & 57 \\
\hline 5 & Febi & 70 \\
\hline 6 & Rianti Rasdin & 57 \\
\hline 7 & Salwa Mahendra & 40 \\
\hline 8 & Muh.Difky & 65 \\
\hline 9 & Aang & 65 \\
\hline 10 & Alif Miftahul Fajar & 58 \\
\hline 11 & Alip & 60 \\
\hline 12 & Amanda Sari & 59 \\
\hline 13 & Andi Zashkia Ramadhani & 65 \\
\hline 14 & Arnita & 59 \\
\hline 15 & Avrilya Herasya & 65 \\
\hline 16 & Gerin Ahmad & 80 \\
\hline 17 & Hardiansyah & 45 \\
\hline 18 & Muh. Adiakza Yusuf & 65 \\
\hline 19 & Muh.Fahril & 52 \\
\hline 20 & Muh.Farel & 75 \\
\hline 21 & Farhan & 64 \\
\hline 22 & Muttiara Pandy & 80 \\
\hline 23 & Nadia Vega & 65 \\
\hline 24 & Peggi Sukmawati & 65 \\
\hline 25 & Ripaldi & 65 \\
\hline & & \\
\hline
\end{tabular}




\begin{tabular}{|c|l|c|}
\hline 26 & Saldyansyah & 60 \\
\hline 27 & S.Ali Al-Jawad & 70 \\
\hline 28 & Sharah & 55 \\
\hline 29 & S.M.Furqon Al-Jawad & 45 \\
\hline 30 & Tenri Azza Annas & 95 \\
\hline 31 & Ulfa Dewiyanti & 75 \\
\hline 32 & Miftahul Khaer & 60 \\
\hline 33 & Muh. Ibrahim & 50 \\
\hline \multicolumn{2}{|c|}{ Jumlah : $\mathbf{3 3}$} & $\mathbf{2 0 2 9}$ \\
\hline
\end{tabular}

\section{c) Observasi}

Sasaran observasi penelitian adalah aspek-aspek proses pembelajaran yang dilakukan guru dan aktivitas siswa dalam kegiatan pembelajaran, yaitu aspek, afektif dan psikomotor yang berhubungan dengan materi pokok menulis cerita karangan khususnya karangan deskripsi dan narasi. Data hasil penilaian baik kognitif (tertulis) maupun afektif dan psikomotor (pengamatan) untuk siswa, dan indikator aspek-aspek proses pembelajaran yang dilakukan guru dalam kegiatan pembelajaran sesuai dengan instrumen pengamatan.

Data hasil penilaian baik kognitif (tertulis) maupun afektif dan psikomotor (pengamatan) untuk siswa dan indikator aspek-aspek proses pembelajaran yang dilakukan guru dalam kegiatan pembelajaran sesuai dengan instrumen pengamatan yaitu aspek-aspek proses pembelajaran yang dilakukan guru meliputi perencanaan, kegiatan utama dan pemantapan.

Tahap observasi pada siklus I tercatat sikap yang terjadi pada setiap siswa terhadap pelajaran Bahasa Indonesia. Sikap siswa tersebut diperoleh dari lembar observasi pada setiap pertemuan yang dicatat pada setiap siklus. Lembar observasi tersebut digunakan untuk mengetahui perubahan cara mengajar guru dan sikap siswa selama proses belajar mengajar berlangsung di kelas pada setiap pertemuan.

Hasil Observasi Aktivitas Siswa Kelas V MI DDI I Palopo

\begin{tabular}{|c|l|c|}
\hline No & \multicolumn{1}{|c|}{ Komponen Yang Diamati } & $\begin{array}{c}\text { Hasil Persentase } \\
\text { Siklus I }\end{array}$ \\
\hline 1. & Siswa yang hadir pada saat proses pembelajaran. & $85,84 \%$ \\
\hline 2. & $\begin{array}{l}\text { Siswa yang dapat mengemukakan pendapat, } \\
\text { komentar, dan mengajukan pertanyaan. }\end{array}$ & $71,69 \%$ \\
\hline 3. & Siswa yang dapat merumuskan pendapatnya dengan & $63,63 \%$ \\
\hline
\end{tabular}




\begin{tabular}{|c|l|c|}
\hline & bahasa dan kalimat yang baik. & \\
\hline 4. & $\begin{array}{l}\text { Siswa yang aktif dalam memecahkan masalah yang } \\
\text { diberikan oleh guru. }\end{array}$ & $46,45 \%$ \\
\hline 5. & $\begin{array}{l}\text { Siswa yang melakukan kegiatan lain pada saat } \\
\text { pembelajaran berlangsung. }\end{array}$ & $22,22 \%$ \\
\hline 6. & $\begin{array}{l}\text { Siswa yang mampu mengerjakan soal dan } \\
\text { menganalisanya. }\end{array}$ & $48,48 \%$ \\
\hline
\end{tabular}

\section{d) Refleksi}

Dari rata-rata kelas hasil evaluasi 61,48 ada kenaikan dibanding nilai ratarata kelas hasil tes sebelumnya yang hanya 49,090. Namun hasil tersebut masih kurang dari batas minimal ketuntasan. Terlihat siswa yang belum tuntas (mendapat nilai $\leq 60)$ sebanyak 17 siswa. Berarti siswa belum dapat menguasai materi menulis cerita karangan, disebabkan media gambar baru di gunakan dalam menulis cerita karangan, belum bisa menggunakan tanda baca serta penulisan kata dengan baik, belum bisa membedakan antara karangan narasi dan deskripsi, kurangnya pemahaman siswa dalam mempelajari/menerima penjelasan dari guru, kurang sistematis guru dalam presentasi dan diskusi kelas, kurangnya pemberian motivasi dari guru, kurangnya bimbingan guru dalam diskusi.

Untuk itu dalam siklus II perlu pembenahan atas kelemahan kelemahan tersebut diatas. Beberapa hal yang harus dilaksanakan dalam siklus II antara lain: memberikan gambar-gambar yang akrab dengan siswa, presentasi jangan terlalu cepat, bimbingan diskusi agar ditambah.

Melihat dari evaluasi pada siklus I terdapat kekurangan yaitu penggunaan media gambar yang berkaitan dengan materi menulis karangan deskripsi dan narasi, maka dari itu perlu di dipenuhi media gambar yang bersifat kontekstual dengan tema yang berbeda, presentasi dan tambah bimbingan diskusi agar dapat meningkatkan hasil belajar siswa.

\section{Deskripsi Siklus II}

\section{a) Perencanaan Tindakan}

Secara lebih rinci dan jelasnya perencanaan pembelajaran yang dilakukan guru dan pengamat pada siklus II ini adalah sebagai berikut: Mempersiapkan peta konsep materi pokok menulis cerita karangan yang telah disusun berdasarkan siklus I. 
1) Menetapkan tujuan pembelajaran yang ingin dicapai.

2) Mempersiapkan rencana pembelajaran materi pokok menulis cerita karangan.

3) Mempersiapkan instrumen pengamatan (observasi) aspek-aspek proses pembelajaran yang dilakukan guru dan aktivitas siswa dalam kegiatan pembelajaran materi pokok menulis cerita karangan.

4) Mempersiapkan media gambar yang akan dipergunakan dalam proses pembelajaran berkaitan dengan materi pokok menulis cerita karangan.

5) Melakukan koordinasi dengan guru kelas dan penjelasan cara pengisian lembar pengamatan (observasi).

\section{b) Pelaksanaan Tindakan}

1) Guru melakukan langkah pembelajaran sesuai dengan RPP dengan berupaya memperbaiki kelemahan aspek-aspek pembelajaran yang telah dilakukannya pada siklus I.

2) Siswa mengikuti kegiatan pembelajaran dan melaksanakan kegiatan sesuai dengan buku panduan kegiatan belajar mengajar dengan berupaya memperbaiki kelemahan-kelemahan yang terjadi pada siklus I, baik yang berhubungan dengan aspek kognitif, aspek afektif maupun psikomotor.

3) Pengamat melakukan pengamatan sesuai dengan instrumen pengamatan tentang aspek-aspek proses pembelajaran yang dilakukan guru dan aktivitas siswa dalam kegiatan pembelajaran yang berhubungan dengan materi pokok menulis cerita karangan.

Adapun data hasil evaluasi dan pengamatan pada siklus II tersaji dalam tabel berikut:

Pada tabel siklus 2 ini, hasil yang diperoleh siswa sesuai dengan caracara yang telah dijelaskan sebelumnya yang terdapat pada siklus 1 , begitupun dengan dengan rumus yang digunakan.

\section{Hasil Evaluasi siklus II}

\begin{tabular}{|c|l|c|}
\hline No & \multicolumn{1}{|c|}{ Nama } & Skor \\
\hline 1 & Muh.Safir & 60 \\
\hline 2 & Sahrul Gunawan & 60 \\
\hline 3 & Nur Ainun & 80 \\
\hline 4 & Nurul Miftahul Jannah & 80 \\
\hline
\end{tabular}




\begin{tabular}{|c|l|c|}
\hline 5 & Febi & 75 \\
\hline 6 & Rianti Rasdin & 70 \\
\hline 7 & Salwa Mahendra & 60 \\
\hline 8 & Muh.Difky & 85 \\
\hline 9 & Aang & 80 \\
\hline 10 & Alif Miftahul Fajar & 80 \\
\hline 11 & Alip & 75 \\
\hline 12 & Amanda Sari & 80 \\
\hline 13 & Andi Zashkia Ramadhani & 80 \\
\hline 14 & Arnita & 70 \\
\hline 15 & Avrilya Herasya & 75 \\
\hline 16 & Gerin Ahmad & 90 \\
\hline 17 & Hardiansyah & 85 \\
\hline 18 & Muh. Adiakza Yusuf & 75 \\
\hline 19 & Muh.Fahril & 75 \\
\hline 20 & Muh.Farel & 80 \\
\hline 21 & Farhan & 80 \\
\hline 22 & Muttiara Pandy & 80 \\
\hline 23 & Nadia Vega & 80 \\
\hline 24 & Peggi Sukmawati & 80 \\
\hline 25 & Ripaldi & 75 \\
\hline 26 & Saldyansyah & 75 \\
\hline 27 & S.Ali Al-Jawad & 85 \\
\hline 28 & Sharah & 80 \\
\hline 29 & S.M.Furqon Al-Jawad & 75 \\
\hline 30 & Tenri Azza Annas & 100 \\
\hline 31 & Ulfa Dewiyanti & 80 \\
\hline 32 & Miftahul Khaer & 75 \\
\hline 33 & Muh. Ibrahim & 70 \\
\hline & Jumlah : 33 & \\
\hline & & 2550 \\
\hline
\end{tabular}

\section{c) Observasi}

Sasaran observasi perbaikan pembelajaran siklus II pada dasarnya sama dengan sasaran observasi perbaikan pembelajaran siklus | yaitu aspek-aspek proses pembelajaran yang dilakukan guru dan aktivitas siswa dalam kegiatan pembelajaran, yaitu aspek afektif dan psikomotor yang berhubungan dengan materi pokok menulis cerita karangan.

Analisis data siklus II pada dasarnya sama dengan analisis data siklus I, perbedaannya terletak pada hasil data yang diperoleh, baik yang berhubungan dengan aspek-aspek proses pembelajaran yang dilakukan guru maupun aktivitas 
siswa dalam kegiatan pembelajaran Bahasa Indonesia. Siklus II memiliki perubahan peningkatan kemampuan hasil belajar siswa kelas V Madrasah Ibtidaiyah DDI I Palopo yang lebih baik di bandingkan dengan evaluasi siklus I.

\section{Hasil Observasi Aktivitas Siswa Kelas V Madrasah Ibtidaiyah DDI I Palopo}

\begin{tabular}{|c|l|c|}
\hline No. & \multicolumn{1}{|c|}{ Komponen Yang Diamati } & $\begin{array}{c}\text { Hasil Persentase } \\
\text { Siklus II }\end{array}$ \\
\hline 1. & Siswa yang hadir pada saat proses pembelajaran. & $90,90 \%$ \\
\hline 2. & $\begin{array}{l}\text { Siswa yang dapat mengemukakan pendapat, } \\
\text { komentar, dan mengajukan pertanyaan. }\end{array}$ & $79,79 \%$ \\
\hline 3. & $\begin{array}{l}\text { Siswa yang dapat merumuskan pendapatnya dengan } \\
\text { bahasa dan kalimat yang baik. }\end{array}$ & $70,70 \%$ \\
\hline 4. & $\begin{array}{l}\text { Siswa yang aktif dalam memecahkan masalah yang } \\
\text { diberikan oleh guru. }\end{array}$ & $77,77 \%$ \\
\hline 5. & $\begin{array}{l}\text { Siswa yang melakukan kegiatan lain pada saat } \\
\text { pembelajaran berlangsung. }\end{array}$ & $13,12 \%$ \\
\hline 6. & $\begin{array}{l}\text { Siswa yang mampu mengerjakan soal dan } \\
\text { menganalisanya. }\end{array}$ & $85,85 \%$ \\
\hline
\end{tabular}

\section{d) Refleksi}

Siklus II dilaksanakan 3 kali pertemuan dengan menerapkan media pembelajaran berupa gambar. Pada tahap ini, guru menyampaikan kepada murid tujuan pembelajaran yang ingin dicapai, menciptakan suasana yang membuat murid dapat termotivasi belajar, menyajikan materi pelajaran dengan menampilkan media gambar yang telah dibagikan, menugasi murid membaca dan menulis teks pada gambar, memanggil perwakilan tiap-tiap murid membaca teks di depan kelas, murid ditugasi menceritakan gambar yang diamati, menugasi murid mengerjakan LKS, memberikan pertanyaan yang berhubungan dengan gambar yang dilihat.

Pada kegiatan pembelajaran siklus II, kehadiran murid 90,90\% mengikuti pelajaran. Rasa ingin tahu dan semangatnya semakin menunjukkan peningkatan. Perhatian, motivasi, dan minat murid dalam pembelajaran membaca dan menulis dan mengerjakan soal latihan yang diberikan sangat besar. Hal ini disebabkan oleh penggunaan media gambar yang menarik, memberi hiburan, humoris, serta alur cerita yang memiliki kemiripan dengan dunia murid. Pada akhirnya, minat baca dan menulis yang diberikan dari guru hampir semua murid menyelesaikannya dengan baik. Nilai presentase dan hasil belajar siswa di sekolah MI DDI I Palopo 
mengalami peningkatan yang semula pada siklus I hanya 61,48 dengan presentase sebesar 45,45\% naik pada siklus II menjadi 77,27 dengan presentase sebesar $75,75 \%$.

\section{Pembahasan}

\section{a. Siklus I}

Dari data-data yang telah didapat bahwa pelaksanaan pembelajaran pada tiap- tiap siklus sangat bervariasi terlebih kekurangan/kelemahannya. Pada siklus I rata-rata prestasi kelas yang diambil dari nilai evaluasi sudah ada peningkatan dari 49,090 menjadi 61,48. Prestasi individu siswapun mengalami peningkatan dari 33 siswa yang menjadi subjek penelitian, 3 siswa yang berada dalam kategori sangat kurang menjadi 0 siswa. 2 siswa $(6,060 \%)$ memperoleh nilai dibawah $\leq 40 ; 15$ siswa $(45,45 \%)$ memperoleh nilai dibawah $\leq 60 ; 15$ siswa $(45,45 \%)$ memperoleh nilai di bawah $\leq 80$; 1 siswa $(3,030 \%)$ memperoleh nilai dibawah $\leq 100$. Dari data diatas perlu adanya perbaikan/penyempurnaan pada siklus II karena masih terdapat 17 siswa yang belum memenuhi standar. Penampilan guru, pemahaman materi, pemberian motivasi, bimbingan pelaksanaan diskusi maupun dalam pemahaman materi yang menjadi kelemahan pada siklus ini.

\section{b. Siklus II}

Pada siklus II rata-rata prestasi kelas yang diambil dari nilai evaluasi mengalami peningkatan yang sangat signifikan dari 61,48 menjadi 77,27 . Prestasi individu siswapun mengalami peningkatan dari 33 siswa yang menjadi subjek penelitian, 15 siswa yang berada dalam kategori cukup pada siklus I menjadi 3 siswa. Siswa yang berada dalam kategori baik meningkat dari 15 siswa menjadi 25 siswa. Kategori sangat baik meningkat dari hanya 1 siswa menjadi 5 siswa. Perbaikan kekurangan pada siklus I menjadi treatment pada siklus ini. Dari uraian pada siklus II diatas indikator kerja yang telah ditetapkan tercapai, maka siswa kelas V Madrasah Ibtidaiyah DDI I Palopo Semester I Tahun Pelajaran 2016/2017 telah tuntas dalam pembelajaran menulis cerita karangan mata pelajaran Bahasa Indonesia.

\section{c. Pembahasan Antar Siklus}


Dari uraian tiap-tiap siklus dapat peneliti simpulkan bahwa dalam setiap siklus terlihat ada peningkatan dibanding keadaan pada siklus sebelumnya, baik prestasi belajar yang diukur melalui tes maupun dari hasil pengamatan ketika kegiatan berlangsung. Peningkatan antara kondisi awal dengan siklus 1 khusunya pada rata- rata prestasi kelas dari 49,090 (Prasiklus) menjadi 61,48 (siklus I) akan tetapi, hasil yang diperoleh masih sangat jauh dari target ketuntasan. Hal ini disebabkan antara lain: bagi siswa pembelajaran menulis karangan adalah hal yang masih membingungkan, siswa belum terbiasa menulis cerita karangan. Sebab selama ini pembelajaran menulis berlangsung secara tradisional atau sekedar hanya menulis hal-hal yang penting saja di dalam buku paket yang disediakan, sehingga kemampuan siswa untuk menulis atau bahkan mengeluarkan pendapat tidak ada, guru pada siklus ini belum begitu dapat menguasai skenario pembelajaran, bagaian mana yang harus diberi penguatan-penguatan dan masih banyak kelemahan/kekurangan pada siklus I ini.

Setelah itu, masuk pada tindakan selanjutnya menjadi semakin tinggi yaitu dari 61,48 (siklus I) menjadi 77,27 (siklus II). Antara siklus I dan II tidak seperti perkembangan pada siklus ini begitu menggembirakan, baik dalam evaluasi maupun dari hasil pengamatan ini desebabkan antara lain: siswa sudah semakin akrab dengan pembelajaran menulis karangan, kerja kelompok pun sudah terlihat kekompakan, keberanian siswa untuk mengeluarkan pendapat sudah baik, gurupun dalam menguasai keadaan/situasi kelas sudah begitu baik terbukti meningkatnya hasil dari pengamatan.

Dalam siklus II inilah kegiatan belajar mengajar mengalami peningkatan yang cukup signifikan. Misal: Untuk lebih jelasnya perubahan dan perkembangan data hasil belajar siswa mulai dari pra siklus, siklus I sampai dengan siklus II dapat dilihat pada tabel berikut ini:

Rekapitulasi Hasil dari prasiklus sampai siklus II

\begin{tabular}{|c|l|c|c|c|}
\hline No & \multicolumn{1}{|c|}{ Nama } & Prasiklus & Siklus I & Siklus II \\
\hline 1 & Muh.Safir & 20 & 45 & 60 \\
\hline 2 & Sahrul Gunawan & 15 & 40 & 60 \\
\hline 3 & Nur Ainun & 40 & 58 & 80 \\
\hline 4 & Nurul Miftahul Jannah & 40 & 57 & 80 \\
\hline 5 & Febi & 60 & 70 & 75 \\
\hline
\end{tabular}




\begin{tabular}{|c|l|c|c|c|}
\hline 6 & Rianti Rasdin & 40 & 57 & 70 \\
\hline 7 & Salwa Mahendra & 15 & 40 & 60 \\
\hline 8 & Muh.Difky & 70 & 65 & 85 \\
\hline 9 & Aang & 60 & 65 & 80 \\
\hline 10 & Alif Miftahul Fajar & 30 & 58 & 80 \\
\hline 11 & Alip & 35 & 60 & 75 \\
\hline 12 & Amanda Sari & 40 & 59 & 80 \\
\hline 13 & Andi Zashkia Ramadhani & 60 & 65 & 80 \\
\hline 14 & Arnita & 40 & 59 & 70 \\
\hline 15 & Avrilya Herasya & 60 & 65 & 75 \\
\hline 16 & Gerin Ahmad & 70 & 80 & 90 \\
\hline 17 & Hardiansyah & 40 & 45 & 85 \\
\hline 18 & Muh. Adiakza Yusuf & 60 & 65 & 75 \\
\hline 19 & Muh.Fahril & 40 & 52 & 75 \\
\hline 20 & Muh.Farel & 70 & 75 & 80 \\
\hline 21 & Farhan & 60 & 64 & 80 \\
\hline 22 & Muttiara Pandy & 70 & 80 & 80 \\
\hline 23 & Nadia Vega & 60 & 65 & 80 \\
\hline 24 & Peggi Sukmawati & 60 & 65 & 80 \\
\hline 25 & Ripaldi & 60 & 65 & 75 \\
\hline 26 & Saldyansyah & 35 & 60 & 75 \\
\hline 27 & S.Ali Al-Jawad & 65 & 70 & 85 \\
\hline 28 & Sharah & 40 & 55 & 80 \\
\hline 29 & S.M.Furqon Al-Jawad & 40 & 45 & 75 \\
\hline 30 & Tenri Azza Annas & 85 & 95 & 100 \\
\hline 31 & Ulfa Dewiyanti & 60 & 75 & 80 \\
\hline 32 & Miftahul Khaer & 40 & 60 & 75 \\
\hline 33 & Muh. Ibrahim & 50 & 70 \\
\hline & Jumlah : 33 & 2029 & 2550 \\
\hline
\end{tabular}

Data ketuntasan nilai evaluasi siswa pada Siklus I dan II MI DDI I Palopo

\begin{tabular}{|c|c|c|c|c|c|}
\hline $\begin{array}{c}\text { Tes } \\
\text { evaluasi }\end{array}$ & $\begin{array}{c}\text { Interval } \\
\text { nilai }\end{array}$ & Kategori & Frekuensi & Persentase & Penentuan nilai \\
\hline \multirow[t]{2}{*}{ Siklus I } & $\begin{array}{c}\text { Nilai } 7,0 \text { ke } \\
\text { atas }\end{array}$ & Tuntas & 7 & $21,21 \%$ & \multirow{4}{*}{$\frac{\text { frekuensi }}{33} 100$} \\
\hline & $\begin{array}{c}\text { Nilai } 7,0 \text { ke } \\
\text { bawah }\end{array}$ & Tidak & 26 & $78,78 \%$ & \\
\hline \multirow{2}{*}{ Siklus II } & $\begin{array}{c}\text { Nilai } 7,0 \text { ke } \\
\text { atas }\end{array}$ & Tuntas & 30 & $90,90 \%$ & \\
\hline & $\begin{array}{c}\text { Nilai } 7,0 \text { ke } \\
\text { bawah }\end{array}$ & Tidak & 3 & $9,090 \%$ & \\
\hline
\end{tabular}




\section{E. Penutup}

\section{Simpulan}

Penelitian tindakan kelas yang dilaksanakan untuk meningkatkan kemampuan siswa menulis cerita karangan di kelas V MI DDI I Palopo dengan menggunakan media gambar ini telah mampu meningkatkan kemampuan siswa dalam menulis karangan.

Penggunaan media gambar yang digunakan sebagai media dalam pembelajaran menulis cerita karangan ini secara khusus ternyata telah mampu: (a)meningkatkan kemampuan siswa dalam menyusun gambar untuk membuat cerita karangan; (b) meningkatkan kemampuan siswa menyesuaian antara cerita dengan susunan gambar; (c) meningkatkan kemampuan siswa menyusun kerangka karangan dengan melihat gambar; (d) meningkatkan kemampuan siswa menggunakan tanda baca serta penulisan kata yang tepat; (e) meningkatkan kemampuan siswa dalam membedakan jenis karangan; (f) meningkatkan gairah dan kesungguhan siswa dalam pembelajaran menulis; (g) mengurangi kejenuhan dan kebosanan dalam pembelajaran menulis.

Hal itu dapat terlihat dari taraf kemampuan siswa pada tingkat ketuntasan menulis cerita karangan pada pembelajaran Bahasa Indonesia siswa kelas V MI DDI I Palopo pada siklus I sebesar $21,21 \%$ atau 7 orang dari 33 siswa berada dalam kategori tuntas dan $78,78 \%$ atau 26 orang dari 33 siswa berada dalam kategori tidak tuntas. Selanjutnya, pada siklus II persentase ketuntasan belajar siswa sebesar $90,90 \%$ atau 30 dari 33 siswa berada dalam kategori tuntas dan 9,090\% atau 3 dari 33 siswa berada pada kategori tidak tuntas.

\section{DAFTAR PUSTAKA}

Abbas Saleh , Pembelajaran Bahasa Indonesia Yang Aktif Di Sekolah Dasar, (Jakarta: Depdiknas,2006) h.127.Arsyad, Azhar, Media Pembelajaran, Cet. I ; Jakarta : PT.Raja Grafindo Persada, 2006.

— Bahasa Arab dan Metode Pengajarannya : Beberapa pokok pikiran Ujung Pandang, Fakultas Tarbiyah IAIN Ujung Pandang, 1997. 
Asnawir , H. dan M.Basyiruddin Usman, Media Pembelajaran, Cet. I; Jakarta: Ciputat Pers, Juni 2002.

Djuanda Dadan, Pembelajaran Bahasa Indonesia Yang Komunikatif Dan Menyenangkan, (Jakarta: Depdiknas, 2006) , hal 102.

Donny, Michael."Penggunaan Media Gambar Dalam Proses Belajar Mengajar,"Blog Agus Ramadhani. http://pendas 2013. blogspot.co.id/2013/01/penggunaan-mediagambar-dalam-proses. html (01 Mei 2016)

Haryadi Dan Zamzani, Peningkatan Ketrampilan Berbahasa, ( Yogyakarta: Depdiknas : 1997) , hal. 78-81

Karyadi Joko,"Peningkatan Keterampilan Menulis Karangan dengan Model Pembelajaran Kooperatif Siswa Kelas III SD Negeri 3 Urutsewu Ampel Boyolali",(SkripsiSebelas Maret:Boyolali, 2010), h.22 ( diakses 01 Mei 2016)

Khaeruddin, "IImu Pendidikan Islam," Cet.I ; Berkah Utami, 2002.

Gei The Liang , Terampil Mengarang, (Yogyakarta: Andi, 2002)

Maryani T.Permana,"Meningkatkan Kemampuan Siswa dalam Menulis Karangan Melalui Penggunaan Media Gambar Seri di Kelas V SDN Cibulan II Desa Cibulan Kecamatan Lemahsugi Kabupaten Majalengka", (Skripsi-Universitas Pendidikan Indonesia:Majalengka, 2009), h.2. ( diakses 25 April 2016 )

Muhadi,Penelitian Tindakan Kelas Panduan Wajib Bagi Pendidik, Cet.I ; Yogyakarta: Shira Media,2011.

Muslich, Masnur. Melaksanakan PTK itu Mudah, Cet.Vl; Jakarta: Bumi Aksara,2012.

Nurdjan, Sukirman, dan Edhy Rustan, Kunci Sukses Berbahasa Indonesia, Palopo, Desember 2010.

Nurjamal, Daeng , et.al. Terampil Berbahasa, Cet.Il; Bandung: Bumi Aksara 2011.

Pratiwi Yuni , Bahasa Indonesia, (Yogyakarta: Universitas Terbuka,2007), h.6.

Profil Madrasah Ibtidaiyah, dokumentasi Madrasah Ibtidaiyah MI DDI I Palopo, 22 Agustus 2016.

S. Sardiman, Arief dkk, Media Pendidikan Cet. I ; Jakarta : Rajawali, 1996.

Sanjaya, Wina, Penelitian Tindakan Kelas, (Cet.IV; Bandung: Kencana Prenada Media Group, 2012), h. 53. 
Suhertian,A. Piet.,konsep dasar dan teknik supervise pendidikan, (Cet;I Jakarta: Rineka Cipta, 2000), hlm, 60.

Septiani Tika, "Peningkatan Keterampilan Menulis Karangan Deskripsi Melalui Model Pembelajaran Kooperatif Tipe Concept SentenceDengan Teknik Pengamatan Objek Langsung Pada Siswa Kelas XA SMA Negeri Wangon Kabupaten Banyumas",(Skripsi-UNNES:Banyumas,2011), h.25. ( diakses29 April 2016)

Thok, Tugino. "Media Belajar Tempat Berbagi IImu dan Pengalaman," Blog Tugino Thok. http://mastugino.blogspot.co.id/2012/12/menyusun-paragraf-berdasarkangambar.html (01 Mei 2016)

Wiyanto, Asul , Terampil Menulis Paragraf, Cet.Il; Jakarta: Wacana Pustaka, Juli 2006.

Zulela, Pembelajaran Bahasa Indonesia, Cet.Il; Bandung: PT.Remaja Rosdakarya,2012. 